\title{
Trends in Rent in Off- Campus Student Accommodation In Federal Public Universities In Southern Nigeria
}

\author{
Mbee, Daniel Mbee Prof. Osigbemeh Akpoghomeh \\ Department of Geography and Environmental Management, Faculty of Social SciencesUniversity of Port \\ Harcourt, Nigeria. \\ Director, Centre for Logistics and Transport Studies, University of Port Harcourt,Port Harcourt
}

\begin{abstract}
Residential accommodation in major cities in Nigeria is limited and often very expensive to rent. The value of residential accommodation however varies from one location to the other. This study attempted to study the spatial trends in the value of student accommodation in southern Nigerian universities. The study adopted the cross sectional research design and to this end used both primary and secondary data. The study relied on Taro Yamane formula and the proportional allocation method to determine the sample size and to distribute the sampled respondents across the various selected universities respectively. In all, 798 respondents were interviewed using the structured and semi structured questionnaire but 762 copies of the questionnaire were retrieved.Simple random sampling technique was deployed in administering the copies of the questionnaire. The data from the field were analyzed using a combination of descriptive and inferential statistics. The study found that there is significant variation in the rental pattern of student accommodation across the selected universities. Moreover, within the same geopolitical zone in the southern, variation in rent also exists. Arising from the findings, the study therefore recommended that government should build massive student housing so that there will be uniformity in rental value.
\end{abstract}

Key words: Student accommodation; Rent

\section{INTRODUCTION}

Nigerian universities are currently experiencing exponential increase in student enrollment(Osunade and Ogundele,2012). Student enrollment in public universities in Southern Nigeria has risen by over 35\% between 1970 and 2014 (NUC, 2015). Currently, there are over 1.2 million students across the 17 public universities in southern Nigeria. The increase is consequent upon the increase in the population growth of Nigeria and the quest for paper qualification (UNESCO, 2012; Ubhenin, 2010 and NPC, 2006). It will be significant to note that one third of the populations (55.3 million) are youthful populace of 10 and 24 years old. The consequence is that Nigeria has a very large proportion of the Nigerian population who are of school going age (UNFPA, 2011). With increasing student population therefore, Nigerian universities require massive investment in housing to accommodate her students. In the last couple of years, there have been serious attempts at increasing housing delivery in Nigerian universities via the private sector. Earlier approaches which advocated the central role of government in housing delivery are now silenced hence giving way to marketbased system where the private sector dictates (Edukugbo, 2006; World Bank, 2013).

Notwithstanding the interventions in student housing supply on the campuses, the total available bed spaces stand at 174563 (Mbee, 2016). The deficit in student accommodation on campus coupled with the poor sanitary condition of the existing ones have forced students to scramble for off-campus accommodation where the housing situation is not any different or better (Needs Assessment Report,2012). The National Housing Policy (2012) estimated the urban housing deficit to be approximately 5 million housing units while the rural accommodation scarcity stood at 3.2 million. Hence, it was predicted that about 700,000 housing units had to be constructed annually to deal with these deficits by the year 2000. Lately, a United Nations study situated the total housing deficiency at 17 million units while National Bureau of Statistics (2013) projection is between 12 and 14 million housing units. Clearly, a high young population, increasing urbanization and changes in household characteristics are exerting a significant influence on the overall demand for housing.

Housing generally provides satisfaction to households' members and students alike. Its location and the facilities it offers are additional comfort derived from it (UN Habitat, 2012). The amount a student pay as rent is therefore a function of the satisfaction he will derive from the house and the prevailing economic rent in the area. Student accommodation rent in public federal universities has undergone various changes over time (NUC, 2012 and Esenwa, 2012). Yet, it is not often clear whether accommodation value increases or decreases consistently in real terms over time. More often than not students protest the outrageous amount being paid on rent. Students in Nigerian universities have also asserted that student accommodation rent is 'too high'; 'increasing rapidly'; 
'rising'; and 'unaffordable to certain groups of students' an 'skyrocketing' (Needs Assessment Report,2012 and Ekwowusi,2012 ). Arising from the above, this study aims at determining the rental trend of off-campus student accommodation in federal public universities and the duration for rent review.

\section{METHODOLOGY}

The study adopted a cross sectional study and the study population were students in federal public universities in southern Nigeria. Primary and secondary data were relied upon. Primary data was collected using the questionnaire. Seven universities were randomly selected from the 17 existing federal universities. To determine the sample size of students, the Taro Yamane formula was applied on the total sample frame of

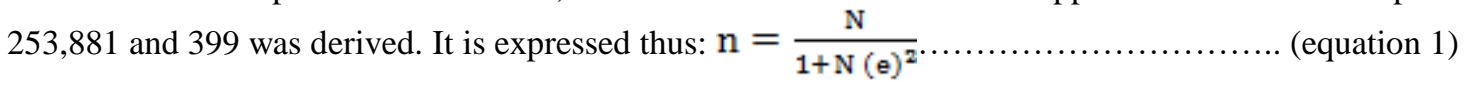

Where:

$\mathrm{N}=$ total population size $(253,881)$

$1=$ is a constant

$\mathrm{e}^{2}=$ level of significance $(0.05)$

In view of relative small size of the number got, the number was multiplied by two. Therefore, the sample size of the study was 798 and to this sampled population copies of questionnaire were systematically administered out of which 762 representing $95.5 \%$ of the distributed copies of questionnaire were correctly filled and retrieved. Analysis was based on the 762 copies retrieved. Simple percentage and the Analysis of Variance (ANOVA) were used in data analysis. Analysis of Variance (ANOVA). It is expressed as:

$$
K=(N-1) \frac{\sum_{i=1}^{g} n_{i}\left(\bar{r}_{i \cdot}-\bar{r}\right)^{2}}{\sum_{i=1}^{g} \sum_{j=1}^{n_{i}}\left(r_{i j}-\bar{r}\right)^{2}},
$$

where:

$$
\begin{array}{ll}
\circ & n_{i} \text { is the number of observations in group } i \\
\circ & r_{i j} \text { is the rank (among all observations) of observation } j_{\text {from group } i} \\
\circ & N_{\text {is the total number of observations across all group }}
\end{array}
$$

Although for speed and accuracy the SPSS 12.0 was used.

\section{Study Area}

Southern Nigeria is located between latitude $3^{\circ}$ and $14^{\circ}$ East and between longitude $4^{\circ}$ and $14^{\circ}$ North. Nigeria shares borders with the republic of Benin to the west, Niger to the north and Chad and Cameroun to the east. The Atlantic Ocean's Gulf of Guinea is to the south of the country. Nigeria is administered as a Federal Republic, having gained independence from the British colonial masters October 1st 1960 (World Bank,2013). The country is divided into six political zones with 36 states as well as the Federal Capital Territory, Abuja. Southern Nigeria was a British protectorate in the coastal areas of modern-day Nigeria, formed in 1900 from union of the Niger Coast Protectorate with territories chartered by the Royal Niger Company below Lokoja on the Niger River. The Lagos colony was added in 1906, and the territory was officially renamed the Colony and Protectorate of Southern Nigeria. In 1914, Southern Nigeria was joined with Northern Nigeria Protectorate to form the single colony of Nigeria. The unification was done for economic reasons rather than political.

There are 17 states scattered in the three geopolitical zones that make up southern Nigeria. United Nations Statistics Division (UNSD, 2010) puts the South-West zone population with six states at 27, 266,257; the six states in the South-South zone at 21,014,655; the five states in the South -East zone at 16,381,729. The southern Nigerian population comprises two major tribes: the Igbo in south east and Yoruba in the South. In the south south there is the Ijaw, Efik, Ibibio, Ogoni and Benis among others (Osuide, 1988).The economy of southern Nigeria is driven by oil and gas, maritime and commerce. Southern Nigeria has significant renewable and nonrenewable resources, some of which have not been fully exploited. Its most profitable minerals include crude petroleum, natural gas, cocoa and coal. 122 Nigeria's oil reserves now comprise $80 \%$ of federal government revenue and $90 \%$. Major agricultural products in Nigeria include: cocoa, cassava (tapioca) yams, and rubber. Livestock and other products in Nigeria include: sheep, goats, cattle, pigs, fish, and timber of exports (FGN, 2010). There are 17 federal universities and 17 state owned universities in southern Nigeria (NUC, 2012). There also exists numerous research institutions established by different levels of government. However, World Bank (2012) reports that poverty has steadily increased, with approximately $70 \%$ of the population below the poverty line in 2007. 
Figure 1showing map of the study area

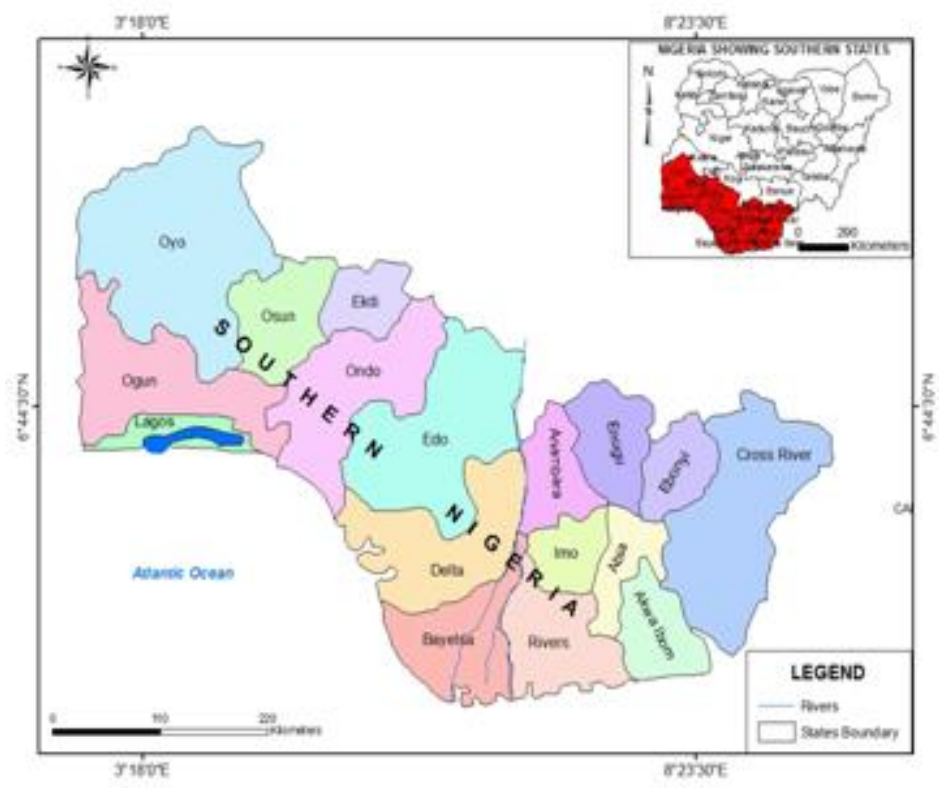

III. RESULTS AND DISCUSSIONS

The pattern of rental value of student housing in southern Nigeria is demonstrated in the table 1 . It is shown that out of the 762 sampled students $35.9 \%$ of the students pay below $\$ 25,000$ as rent per annum while $20.2 \%$ pay between $\$ 25,000$ and $\$ 50,000$ as rent per annum. On the average, over half $56 \%$ of the sampled students pay between $\$ 25,001$ and $\$ 50,000$ on rent per annum. (See table 1). The table shows that among the universities sampled, students who pay below $\$ 25,000$ are most in UI and fewest in NAU. 35.9\% of them pay below twenty five thousand naira on rent. However, $60 \%$ of the respondents in UI pay below $\$ 25,000$. In UNIBEN 55.5\% of the respondents sampled also pay below $\$ 25,000$. As reported in the table, 45.1\% of respondents in FUTO expend same amount. Additionally, 36.1\% and 27.2\% of respondents in FUTA and UNILAG pay $\$ 25,000$ on rent per annum. The percentage of respondents who pay $\$ 25000$ on accommodation differ in UNIPORT and NAU. Precisely $13.3 \%$ and $5.1 \%$ of the respondents in the both Universities correspondingly pay below $\$ 25,000$ on accommodation. In spite of the fact that over a third of the sampled students pay below 25,000 per annum, $20.2 \%$ of the total students in the study area pay between $\$ 25,000$ and N50,000. Among the universities, students in FUTA pay the highest amount of rent per annum. The scenario is different in NAU and in other institutions sampled. Exactly, $29.6 \%$ of respondents in NAU pay between $\$ 25$, 000 and $\$ 50,000$ on accommodation per annum while $28 \%$ of respondents in FUTO are those that pay the amount on rent in a year. Aside this, $20.4 \%$ of the respondents in UNILAG and $16.5 \%$ of students in UNIBEN expend between $\$ 25,000$ and $\$ 50,000$ also on rent yearly. Although in UI only $14.9 \%$ of the respondents are those that commit this same amount on rent while only $5.1 \%$ of the respondents in UNIPORT pay this amount. (See table 1).

Table 1: Pattern of Rental Value of Students Housing Per annum in Southern Nigerian Universities

\begin{tabular}{|l|l|l|l|l|l|l|l|l|l|l|l|l|l|l|l|l|}
\hline Rental value & \multicolumn{2}{|c|}{ FUTA } & \multicolumn{2}{c|}{ FUTO } & \multicolumn{2}{c|}{ NAU } & \multicolumn{2}{c|}{ UNIBEN } & \multicolumn{2}{c|}{ UI } & \multicolumn{2}{c|}{ UNILAG } & \multicolumn{2}{c|}{ UNIPORT } & \multicolumn{1}{c|}{ TOTAL } \\
\hline & NO & $\%$ & NO & $\%$ & N0 & $\%$ & NO & $\%$ & NO & $\%$ & NO & $\%$ & NO & $\%$ & NO & $\%$ \\
\hline Below 25,000 & 26 & 36.1 & 37 & 45.1 & 5 & 5.1 & 91 & 55.5 & 61 & 60.4 & 40 & 27.2 & 13 & 13.3 & 273 & 35.9 \\
\hline $25,001-50,000$ & 25 & 34.7 & 23 & 28.0 & 29 & 29.6 & 27 & 16.5 & 15 & 149 & 30 & 20.4 & 5 & 5.1 & 254 & 20.2 \\
\hline $50,001-75,000$ & 11 & 15.3 & 17 & 20.7 & 25 & 25.5 & 28 & 17.1 & 13 & 12.9 & 19 & 129 & 18 & 13.4 & 131 & 17.2 \\
\hline $75,001-100,000$ & 9 & 12.5 & 2 & 2.4 & 30 & 30.6 & 5 & 3.0 & 7 & 6.9 & 14 & 9.5 & 9 & 9.2 & 76 & 10.0 \\
\hline Abovel00,000 & 1 & 1.4 & 3 & 3.7 & 9 & 9.2 & 13 & 7.9 & 5 & 49 & 44 & 30 & 53 & 54.0 & 127 & 16.7 \\
\hline TOTAL & 72 & & 82 & & 98 & & 164 & & 101 & & 147 & & 98 & & 762 & 100 \\
\hline
\end{tabular}

Source: Researcher's fieldwork, 2014

Also, UNIPORT has the smallest number of students who pay between $\$ 25,000$ - $\$ 50,000$ per annum on rent. The kind of accommodation occupied by UNIPORT students may have relationship with what they pay. Moreover, $17.2 \%$ of them expend between fifty thousand and one naira and seventy five thousand naira on rent per annum. However, $25.5 \%$ of the sampled students who pay this amount are in NAU. Thus NAU is on top of other universities in terms of number of students that pay between N50, 000 and $\$ 75,000$ naira per annum. Interestingly, $20.7 \%$ of respondents in FUTO also pay this amount. But in UNIBEN, it is $17.1 \%$ of the students 
that pay this amount while in FUTA, it is $15.3 \%$ of the students. Additionally, $13.4 \%$ of the respondents in UNIPORT pay between fifty thousand and one naira and seventy five naira. This is also the case with $12.9 \%$ of students in UI and UNILAG correspondingly. (See table 4.10). Both universities incidentally are with the number of students who pay between $\$ 75,000$ and $\$ 100,000$ per annum. However, it is observed that $16.7 \%$ of the total sampled students in the study area pay above one hundred thousand naira yearly on rent. (See table 4.10). Furthermore, a cursory look at the table further shows that exactly, 54\% of the students which is over half of the proportion of the students who pay N100,000 on rent are from UNIPORT. It is worthy to note that based on the result presented in the table under reference that it is only in UNIPORT that about half of the students pay above one hundred thousand naira on rent per annum on rent. It is pertinent to note that UNIPORT is located in a major city in Nigeria. Port Harcourt is the home of many multinational corporations. This has pushed up the population size of the city. According to NBS (2014), Port Harcourt has acute housing shortage thus existing accommodation are overpriced. This in part seems to explain why more respondents in UNIPORT pay more on off campus accommodation than other schools.

Nonetheless, in the other universities sampled, 9.2\% of all the students in NAU pay above $\$ 100,000$ while $7.9 \%$ of them in UNIBEN also pay this amount. Likewise, $4.9 \%$ and $3.7 \%$ of the students sampled in UI and FUTO FUTA pay above $\$ 100,000$ are in UI and FUTO respectively. Besides, $1.4 \%$ of the students in FUTA also pay above $\$ 100,000$ are in FUTA. (See table 4.10). A situation whereby only $1.4 \%$ of the students in FUTA pay above $\$ 100,000$ suggests that the it has the lowest proportion of the sampled students who pay above N100,000 per annum on rent. It also suggests the nature of the property market and the economy in Akure, the city where the university is located. Akure, the capital of Ondo State largely depends on the federal government handout (NBS, 2014). The property market in Akure is generally characterized by insufficient credit (Oloyede,2013).

Conversely, out of all the students sampled in the study area only $10 \%$ of them pay between seventy five thousand and one naira and one hundred thousand naira only on accommodation per annum. Yet, precisely $30.6 \%$ of the students in NAU pay such amount on rent while in FUTA it is $12 \%$ of the students pay the same amount as well. As indicated also in the table 1, NAU has the highest number of students who pay between seventy five thousand and one naira and one hundred thousand naira on rent while FUTO owns the lowest ratio of students in this bracket. Also evident in the table is that $9.5 \%$ of the respondents in UNILAG and $9.2 \%$ respondents in UNIPORT pay between seventy five thousand one naira and one hundred thousand on rent per annum. On the other hand $6.9 \%$ of respondents in UNIBEN pay the same amount whereas $2.4 \%$ of respondents in FUTO are those paying between seventy five thousand and one naira and one hundred thousand naira only.

Figure 1: The pattern of rental value of student housing in southern Nigeria.

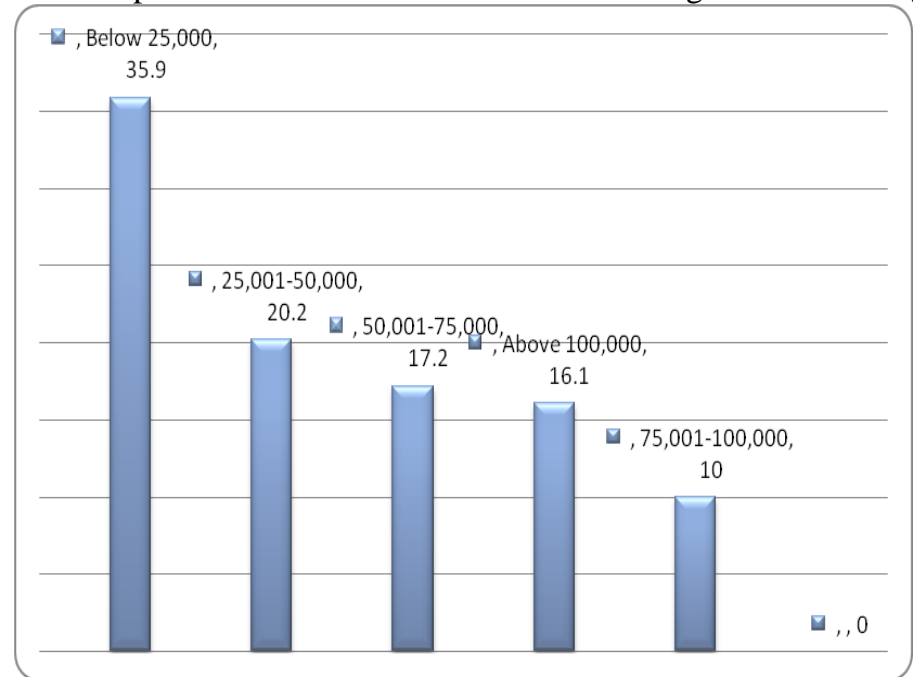

The graph shows that most students pay below N25.000 per annum as students.

\section{Rent review}

The study found that rent of student accommodation is reviewed yearly, after two years and also after more than two years. The table 2 below shows the frequency students experience rent review.

Table 2: Frequency of Increase in Rental Value

\begin{tabular}{|l|l|l|}
\hline Rent Review & Frequency & Percentage \% \\
\hline Annually & 165 & 21.6 \\
\hline
\end{tabular}




\begin{tabular}{|l|l|l|}
\hline Biannually & 315 & 41.4 \\
\hline More than 2 years & 282 & 37 \\
\hline Total & $\mathbf{7 6 2}$ & $\mathbf{1 0 0}$ \\
\hline
\end{tabular}

Source: Researcher's Field Work 2016

As shown by the table 2, it is evident that majority of students experience an upward review of rent after two years. Students in this category represent $41.4 \%$ of the entire sample size. On the other hand, $37 \%$ of them experience increase in rent after more than two years. The table 2 also shows that less than one third of the students sampled experience upward review in rent annually. Students in this category constitute only $21.6 \%$ of the entire respondents sampled in the study. It can therefore be inferred that rent view in Nigeria is usually at the discretion of the landlords and this they do arbitrarily. This brings to the fore the efficacy of the Nigerian rent edict of 1984 where in government on the pretext of protecting the urban dwellers from being pushed off the open market in the course of securing accommodations by putting a ceiling on the maximum rent payable on all classes of residential properties.

\section{Hypothesis One}

$\mathbf{H}_{\mathbf{0}}$ : There is no statistically significant variation in the rental value of student housing in

Southern Nigerian universities.

$\mathbf{H}_{1}: \quad$ There is.

This hypothesis was analyzed using the single factor Analysis of Variance.

The analysis of Variance (ANOVA) statistic as presented in the table below 3 shows that the F statistics (0.597714) is less than the F critical (2.3239). This implies that there is no significant variation in the rental value of student housing in the Universities in Southern Nigeria. Furthermore, the P-Value of 0.729 confirms the non-existence of a significant variation in the rental value of student housing in Southern Nigerian universities. We therefore accept the null hypothesis which says that there is no significant variation in the rental pattern of student housing in Southern Nigerian universities.

Table 3 Summary of the One-Way ANOVA For Rental Value of Students in Southern Nigerian universities

\begin{tabular}{|c|c|c|c|c|c|c|c|}
\hline S/N & Groups & $\begin{array}{c}\text { Sum of } \\
\text { Squares(SS) }\end{array}$ & DF & Mean Square (MS) & F-Calculated & P-Value & F-Critical \\
\hline 1 & $\begin{array}{c}\text { Between } \\
\text { Groups }\end{array}$ & 1385.485714 & 6 & 230.9142857 & 0.597714 & 0.729 & 2.445 \\
\hline 2 & $\begin{array}{c}\text { Within } \\
\text { Groups }\end{array}$ & 10817.2 & 28 & 386.3285714 & & & \\
\hline & TOTAL & 12202.68571 & 34 & & & & \\
\hline
\end{tabular}

Source: Researcher's computation, 2016.

Table 4 indicates that $F$ statistics value is 0.501 and the $F$ critical is 3.885 . Clearly, from the table, the $F$ calculated is less than the F critical. This therefore suggests that there is no significant variation in the rent values of student housing in the different geopolitical zones within Southern Nigerian Universities. Additionally, the table notes that the P-value of 0.611 is greater than 0.05 level of significance. Accordingly, we accept the null hypothesis which says that there is no statistically significant variation in the rent values of student housing in the universities in the three regions that make up Southern Nigeria.

Table 4 Summary of the One-Way ANOVA For Rental Value of Student Housing Among Regions in Southern Nigerian universities

\begin{tabular}{|c|c|c|c|c|c|c|c|}
\hline S/N & Groups & $\begin{array}{c}\text { Sum of } \\
\text { Squares(SS) }\end{array}$ & DF & $\begin{array}{c}\text { Mean Square } \\
(\mathbf{M S})\end{array}$ & F-Calculated & P-Value & F-Critical \\
\hline 1 & $\begin{array}{c}\text { Between } \\
\text { Groups }\end{array}$ & 173.937 & 2 & 86.968 & 0.501 & 0.611 & 3.885 \\
\hline 2 & $\begin{array}{c}\text { Within } \\
\text { Groups }\end{array}$ & 2081.222 & 12 & 173.435 & & & \\
\hline & TOTAL & 2255.159 & 14 & & & & \\
\hline
\end{tabular}

Source: Researcher's computation , 2016 


\section{CONCLUSION}

As shown by the study the rent for student housing varies across the seven sampled universities in Southern Nigeria. This experience may be situated within the prevailing social economic condition of the cities where the universities are located. In a generic sense, Nigeria has housing deficit of over 8 million housing stocks. UNHABITAT (2012) underscored this by its report that over 500,000 persons live in informal settlements. In some cities, housing shortage is more severe than the other. According to NBS (2013), Port Harcourt has acute housing shortage thus existing accommodation are overpriced. This in part seems to explain why among the sample institutions students in UNIPORT pay the highest amount on rent. On the contrary, FUTA has the lowest proportion of students who pay the least on student accommodation. This may not be unconnected with the property market and the general economic situation in Akure, the city where the university is located. Akure, the capital of Ondo State largely depends on the federal government handout (NBS, 2013). The property market in Akure is generally characterized by insufficient credit (Yussuff, 2010).

\section{REFERENCES}

[1] Esenwa, F.O. (2012). Proposal on private sector participation in university hostel development and management, department of physical planning and development, National Universities Commission, Abuja.

[2] Ekwowusi, S. (2012). "Population growth as impetus to sustainable development, The Guardian newspaper, Thursday, September 27 pg 54

[3] Osunade,O and C.O Ogundele (2012). "Evaluation of the University of Ibadan website using webometric ranking parameters," Transnational Journal of Science and Technology, 2 (3): 53

[4] June, A. W. (2006). Facilities play a key role in students' enrollment decisions, study finds [Electronic version]. The Chronicle of Higher Education, 51(21). Retrieved November 26, 2013, from http://chronicle.com.turing.library.northwestern.edu

[5] Mbee, D.M. (2016) Determinants of student housing in southern Nigerian universities. Unpublished Ph.D thesis. Department of Geography and Environmental Management, University of Port Harcourt, Port Harcourt

[6] National Bureau of statistics (2013). Report. Abuja.

[7] National Population Commission (2012). States in Nigeria with area size and population data. 2012: Federal Republic of Nigeria (FRN) Abuja

[8] National Universities Commission (2015). Federal Republic of Nigeria (FRN) Abuja

[9] National Housing policy Federal Republic of Nigeria (FRN) Abuja

[10] Needs Assessment Report (2012) Committee report on needs assessment of Nigerian universities, p $45-47$

[11] South Africa (2011) Department of higher education and training. Report on the Ministerial Committee for the Review of the Provision of Student Housing at South African Universities. I September, 2011.

[12] The Guardian (2012a) "Committee on needs assessment of public universities submits recommendations", Thursday, November 22 pp $47-54$.

[13] The Guardian (2012b) "Report exposes rot in public varsities proposes 189 recommendations" Thursday, November 15, pp. 47-52.

[14] Ubhemin, O. E. (2010). The dynamics of Nigeria's population polices. Africana 4 (2): 20-23

[15] UNDP (2010). Human Development Report HDR 2010. United Nations Development Programme.

[16] United Nations Educational, Scientific and Cultural Organization (2010). Education for all: global monitoring report, 2006. Paris: United Nations Educational, Scientific and Cultural Organization.

[17] United Nations Population Fund UNFPA (2011) Guidelines for Linking Population and Housing Censuses with Agricultural Censuses

[18] UN-HABITAT, (2012). Enabling shelter strategies. Review of experience from two decades of implementation. Nairobi: UN-HABITAT.

[19] World Bank (2013). Country brief: Nigeria. World Bank, Washington DC.

[20] Yusuff, O. (2010) Student access to Housing: A case of Lagos State University, Nigeria Journal of Sustainable Development Vol. 4 no 1, 107-122 